\title{
Case of an Unusual Suprascapular Neuropathy: Case Report and Literature Review
}

\author{
Sıradışı Bir Supraskapular Nöropati Olgusu: \\ Olgu Sunumu ve Literatürün Gözden Geçirilmesi
}

(D) Sevgi ikbali Afşar, (D) Metin Karataş

Başkent University Faculty of Medicine, Department of Physical Medicine and Rehabilitation, Ankara, Turkey

\section{Abstract}

Suprascapular neuropathy is a rare cause of shoulder pain and muscle weakness. Common causes include space-occupying lesions such as paralabral cysts, soft tissue or bone tumors, recurrent overhead activities in athletes, direct trauma, fractures of the scapula and iatrogenic causes. Diagnosis of suprascapular neuropathy can be difficult due to overlap in the clinical presentation with cervical region and other pathologies of the shoulder. We present a 33-year-old male patient admitted to our clinic with complaints of left shoulder pain and arm weakness starting in 8 months ago. The clinical and electrophysiological evaluations confirmed the left suprascapular nerve lesion at suprascapular notch level. This case is presented to emphasize that suprascapular neuropathy should keep in mind in the differential diagnosis of shoulder pain also without of a mass, trauma or excessive physical activity that may cause the neuropathy.

Keywords: Rehabilitation, nerve compression syndromes, electromyography

\section{$\ddot{O z}$}

Supraskapular sinir nöropatisi omuzda ağrı ve kas zayıflığının nadir görülen bir nedenidir. Yaygın görülen nedenler arasında; para-labral kist, yumuşak doku veya kemik tümörleri gibi yer kaplayan lezyonlar, sporcularda tekrarlayan baş üstü aktiviteler, direkt travma, skapula kırığı ve iyatrojenik nedenler yer almaktadır. Supraskapular sinir nöropatisinin klinik prezentasyonu, servikal bölge ve omuz ile ilgili diğer patolojilerle çakışabileceğinden tanısı zor olabilir. Burada; 8 ay önce başlayan sol omuzda ağıı ve kolda güçsüzlük şikayetleri ile kliniğimize başvuran 33 yaşındaki erkek hasta sunulmaktadır. Yapılan klinik ve elektrofizyolojik değerlendirmeler supraskapular çentik düzeyinde sol supraskapular sinir lezyonunu doğrulamıştır. Bu olguyu, omuz ağrısının ayıııcı tanısında, nöropatiye neden olabilecek kitle, travma veya aşıı fiziksel aktivitenin olmadığı durumlarda da supraskapular sinir nöropatisinin akılda tutulması gerektiğini vurgulamak için hazırladık.

Anahtar kelimeler: Rehabilitasyon, sinir basısı sendromları, elektromiyografi

\section{Introduction}

Suprascapular neuropathy is a comparatively rare reason of shoulder pain and muscle weakness, and can be missed along examination. It was first identified by Thompson and Kopell in 1959 (1). Although its incidence and prevalence is not known exactly, $1-2 \%$ of shoulder pain cases have been suggested to originate from suprascapular neuropathy (2). Trauma, pressurecausing lesions (such as hypertrophy of superior or the inferior transverse scapular ligament and ganglion cysts) and repetitive stress are among the well-known reasons of suprascapular neuropathy $(3,4)$. Repetitive overhead activities can lead to stretching of the suprascapular nerve and pressure at the suprascapular notch (SSN) or spinoglenoid notch (SGN) and can result in neuropathy (5). Isolated suprascapular neuropathy cases without a history of trauma, mass or repetitive movements are rare in the literature.

We present a case that presented to our clinic with symptoms of shoulder pain and loss of strength and was found to have suprascapular neuropathy, together with a review of the relevant literature.

\section{Case}

A 33-year-old male patient presented to physical therapy and rehabilitation polyclinic with complaints of shoulder pain and loss of strength in left shoulder muscles. His personal history revealed nothing of significance except migraine. The symptoms had started suddenly approximately eight months ago. The patient stated that he had slept with his left shoulder

Address for Correspondence/Yazıșma Adresi: Sevgi Ikbali Afșar MD, Bașkent University Faculty of Medicine, Department of Physical Medicine and Rehabilitation, Ankara, Turkey Phone: +90 3122126650 E-mail: ikbaliafsar@hotmail.com ORCID ID: orcid.org/0000-0002-4003-3646 Received/Geliş Tarihi: 08.06.2016 Accepted/Kabul Tarihi: 26.06.2018

${ }^{\circ}$ Copyright 2018 by the Turkish Osteoporosis Society

Turkish Journal Of Osteoporosis published by Publishing House. 
fully abducted at night and the shoulder pain had started in the morning. He also expressed that he had very severe shoulder pain at the beginning, and could not perform shoulder movements due to the pain. He had taken non-steroidal antiinflammatory drugs which reduced the pain within a few days after which he noticed weakness in his left arm. He expressed that it was especially difficult to comb his hair as his arms immediately became tired. Cervical vertebrae magnetic resonance imaging (MRI) carried out at another center showed no pathology. The patient was given a diagnosis of shoulder periarthritis and was treated conservatively. The patient's pain decreased further but the weakness in his left arm continued, for which he presented to our clinic. He did not report any history of excessive physical activity, trauma or infection before the onset of the current symptoms.

A physical examination revealed that the range of motion of the neck was normal and painless. Spurling, compression and distraction tests were negative. Significant atrophy of the infraspinatus muscle and slight atrophy of the supraspinatus muscle on the left side was observed (Figure 1). There was pain on left shoulder external rotation with minimum limitation at the end of the range of motion. Examination of muscle strength revealed shoulder abduction 5-/5; flexion, extension and adduction 5/5; external rotation 3/5; and internal rotation $5 / 5$. Examination of sensation and deep tendon reflexes were normal.

Investigations revealed normal posteroanterior chest and left shoulder radiographs. Routine blood tests were also within the normal range. Left shoulder MRI showed tendinitis in supraspinatus tendon, diffuse edema and some atrophy of the supraspinatus and infraspinatus muscles together with minimal fluid in the subdeltoid, subacromial and subscapular bursae (Figure 2a, 2b). With these findings in mind electrophysiological examination was performed.

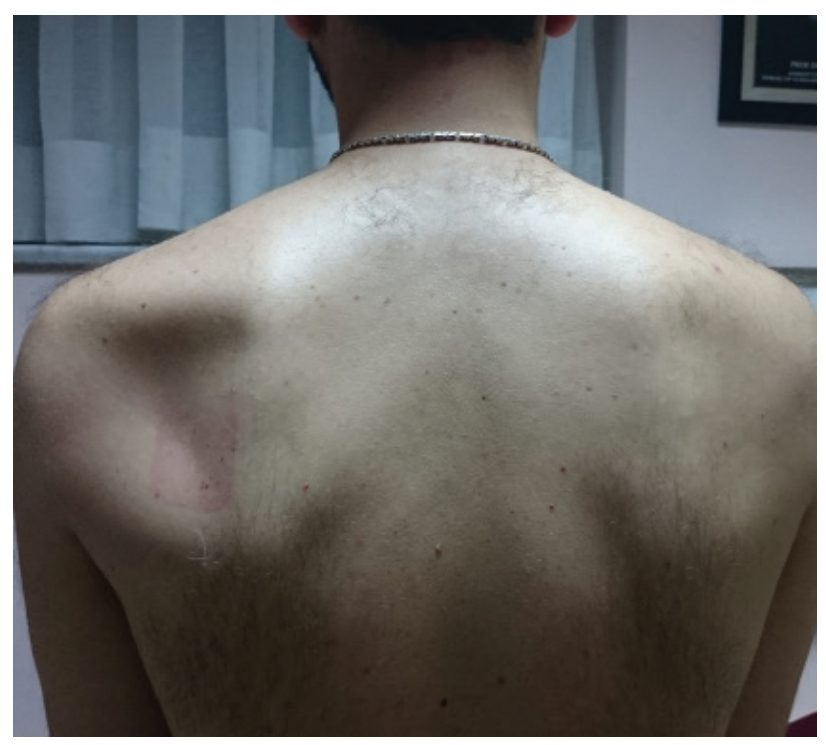

Figure 1. The pre-treatment appearance of left infraspinatus and supraspinatus muscle atrophy
Upper extremity peripheral nerve conduction studies were carried out on both sides. The suprascapular nerve compound muscle action potential (CMAP) responses were recorded from the supraspinatus and infraspinatus muscles with concentric needle electrodes by stimulation with the superficial electrode from the Erb point. According to the obtained results the left suprascapular nerve response latency was increased and the CMAP amplitude was decreased. All other motor and sensory nerve conductions were within normal limits.

Needle electromyography (EMG) showed denervation potentials and chronic neurogenic motor unit action potentials with reduced recruitment in the left supraspinatus and infraspinatus muscles. EMG studies of trapezius, deltoid, biceps, serratus anterior, rhomboids and C5 paraspinal muscles was normal. These findings were found to be consistent with severe axonal involvement of the left suprascapular nerve at the SSN. The
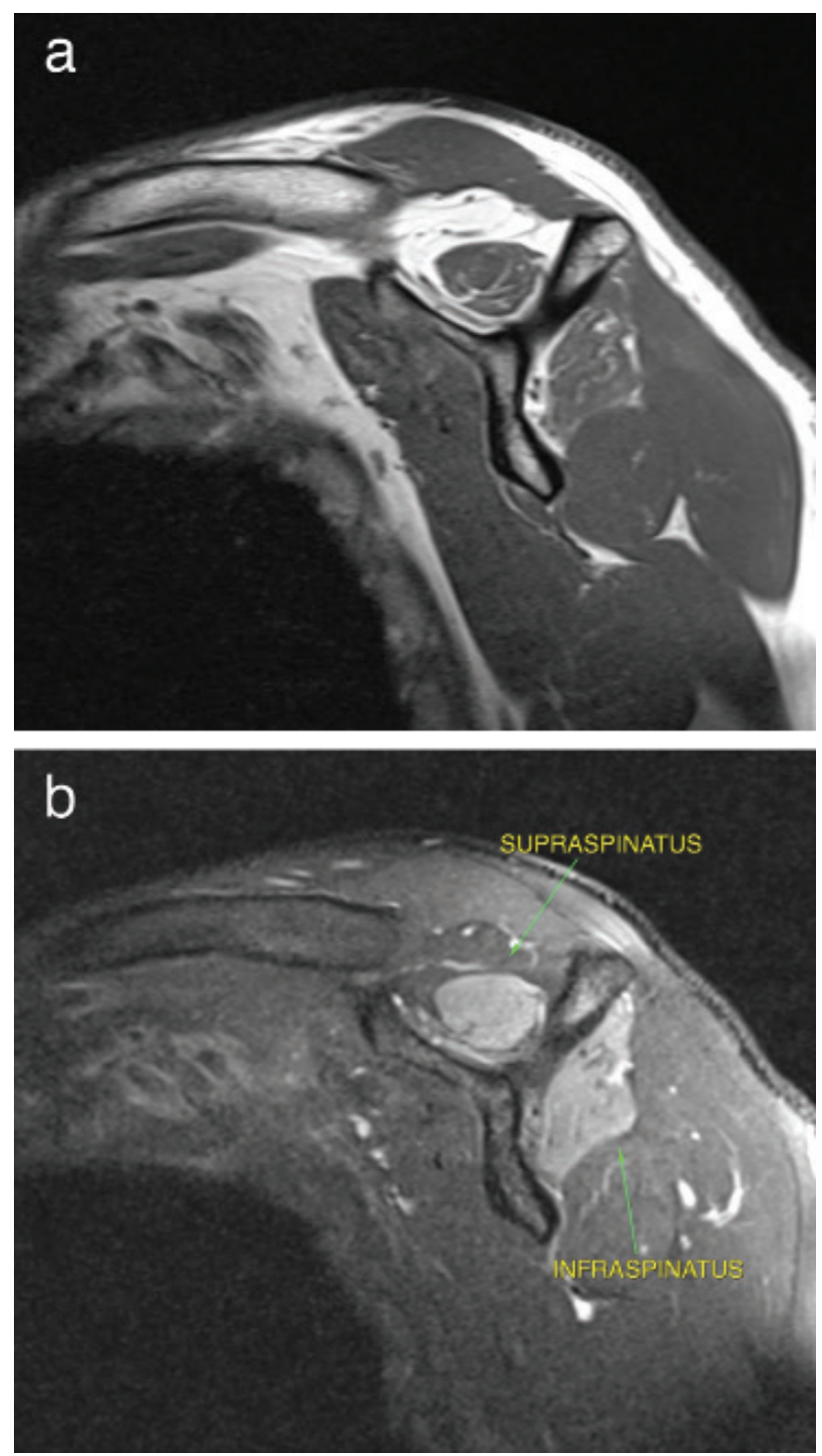

Figure $\mathbf{2}(\mathbf{a}-\mathbf{b})$. Diffuse edema and atrophy of the supraspinatus and infraspinatus muscles on sagittal T1 section (a) and sagittal fat-suppressed PD+T2 section (b) 
patient was included in a physical therapy and rehabilitation program with thermotherapy, transcutaneous electrical nerve stimulation and ultrasound applied to the left shoulder, an exercise program (joint range of motion and stretching exercises, progressive resistive exercises and posture exercises) and neuromuscular electrical stimulation. A home exercise program was organized at the end of the rehabilitation program and follow-up was recommended after the patient's discharge. On follow-up examination three months later, muscle strength had improved almost fully, but partial atrophy was still present in the supraspinatus and infraspinatus muscles (Figure 3). Re-innervation findings were observed in the supraspinatus and infraspinatus muscles on needle EMG. The home exercise program was revised according to the patient's increased muscle strength.

A written informed consent was obtained from the patient for this case report.

\section{Discussion}

The suprascapular nerve is derived from the fifth and sixth cervical roots and then separates from the upper trunk of the brachial plexus and advances at the back of the neck triangle before proceeding below the trapezius.

It reaches the upper edge of the scapula then goes under the transverse scapular ligament, passes the SSN and go into the supraspinatus fossa. Motor fibers of the suprascapular nerve innervate the supraspinatus muscle and the sensory branch innervates the capsule and ligaments of the glenohumeral and acromioclavicular joints. It then extends along the scapula and

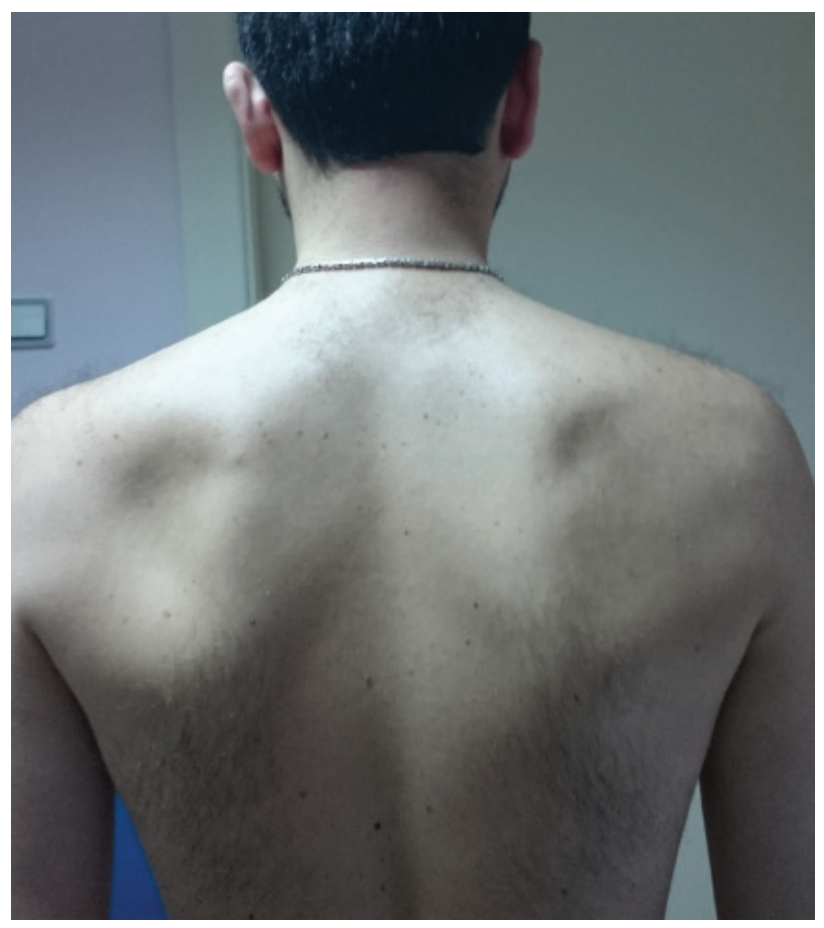

Figure 3. The left infraspinatus and supraspinatus muscles three months after the completion of the rehabilitation program passes the SGN and innervates the infraspinatus muscle $(4,6)$. The region where the nerve is most sensitive to external factors is the SSN and this is the region that is most under pressure. Rarely, entrapment neuropathy can also develop in the SGN (3). Trauma, scapular fractures, paralabral cysts, hematomas, soft tissue tumors or bone tumors are among the common causes of suprascapular nerve injuries. Activities involving repetitive shoulder use and especially volleyball, baseball, swimming, weight lifting and heavy labor have been associated with suprascapular neuropathy in the literature (7-9). Besides this, the condition has also been reported to develop following congenital structural changes of the scapular bone, abnormal transverse scapular ligament, vascular malformations, spinoglenoid notch cyst, iatrogenic injuries during surgical intervention, shoulder arthrodesis and anterior dislocation of the shoulder $(6,10,11)$. When reviewing the literature we observed that suprascapular nerve neuropathy cases developing due to other reasons were rare. A compressive lesion was excluded with MRI in our case. No history of trauma or repetitive overhead movement related to occupational or sports activities was present. The history revealed that the symptom of pain in the left shoulder girdle had started after sleeping with the left shoulder fully abducted for one night. Walsworth et al. (12) published a case who similarly developed suprascapular nerve neuropathy after sleeping with the shoulder in the abducted position. Economides et al. (13) noticed a 23 years old patient with suprascapular nerve damage following post-operative transfer in an inappropriate position. The authors reported that relaxation of the muscles under anesthesia, followed by hyperabduction of the shoulder on transfer, may have resulted in a traction injury.

The pathophysiology of suprascapular nerve entrapment has been identified in numerous case reports in the literature and includes ischemia, edema, microenvironmental changes and deterioration in conduction by reason of tension or compression of the suprascapular nerve (13). Recurrent overhead activities and a trauma that causes scapular fracture or glenohumeral dislocation has been seen as the mechanism of tension (11). It has been reported that the lesion can develop as a result of stretching of the nerve and compression at the the SSN or SGN following repeated overhead activities (5).

If suprascapular nerve damage occurs in the SSN, both the supraspinatus and infraspinatus muscles affected (4). Loss of strength of the external rotator and abductor muscles and shoulder pain are seen (10). Nevertheless, the patients can compensate for the strength loss with other muscles, and therefore may not notice the problem. Fatigue in overhead activities as in our patient is especially quite common. In addition, muscle loss of the supraspinatus can be overlooked due to the trapezius muscle. Atrophy is more evident in the infraspinatus as there is no other muscle at the upper part (4). If the lesion of the suprascapular nerve is at the level of the SGN, infraspinatus muscle is selectively affected (14).

Diagnosis of suprascapular neuropathy can be compelling as the findings may be similar to other pathologies of the shoulder 
and cervical region. Brachial plexopathy, C5-C6 radiculopathy, injury of the rotator cuff muscles and subacromial impingement syndrome should be excluded before a definite diagnosis is made. It is also possible for subacromial impingement syndrome and rotator cuff pathologies to develop as a result of the disruption of the shoulder related to subscapular neuropathy (1). Moreover, massive tears of the rotator cuff muscles caused by traction injury has also been described in the literature (5). The diagnosis is made with a elaborate history, a careful examination, and electrophysiological and radiological investigations. Electrophysiologic testing is necessary to confirm the diagnosis of suprascapular neuropathy. Increased motor latency and reduced CMAP amplitude of the suprascapular nerve, and the presence of denervation findings in the supraspinatus and/or infraspinatus muscles of the needle EMG are generally accepted as diagnostic for lesion of the suprascapular nerve. However, these are not strictly diagnostic criteria that are universally accepted (15). It should not be forgotten that electrophysiological investigations and MRI are methods that complement each other in the diagnosis of suprascapular neuropathy. The sensitivity of EMG and nerve conduction studies is between $74 \%$ and $91 \%$ (16).

While electrophysiologic tests help in the differential diagnosis of brachial plexopathy and cervical radiculopathy, they are also extremely useful in determining patient prognosis (10).

Conservative treatment methods including pain relief, activity modification and physical treatment are initially recommended. In the early stage of treatment, joint range of motion, scapular stabilization and strengthening exercises aim to recover muscle strength and prevent restriction of joint movement. Immediate surgical intervention is recommended in the existence of a tumor, complete nerve injury or any other injury requiring surgical treatment of the shoulder (14).

In conclusion, suprascapular nerve neuropathy should always be come to mind in the differential diagnosis of patients who present with shoulder pain and muscle loss of strength. Electrophysiological investigations and MRI are indispensable in investigating the differential diagnoses and in the determination of the level and location of the lesion. Early recognition and therapy are important to prevent the progress of permanent weakness and atrophy.

\section{Ethics}

Informed Consent: Written informed consent was obtained from the patient for this report.

\section{Authorship Contributions}

Surgical ad Medical Practices: S.I.A., Concept: M.K., Design: M.K., Data Collection or Processing: M.K., S.I.A., Analysis or Interpretation: S.I.A., Literature Search: S.I.A., Writing: S.I.A.

Conflict of Interest: No conflict of interest was declared by the authors.

Financial Disclosure: The authors declared that this case has received no financial support.

\section{References}

1. Thompson WA, Kopell HP. Peripheral entrapment neuropathies of the upper extremity. N Eng J Med 1959;260:1261-5.

2. Clavert P, Thomazeau H. Peri-articular suprascapular neuropathy. Orthop Traumatol Surg Res 2014;100(Suppl 8):409-11.

3. Gosk J, Rutowski R, Wiacek R, Reichert P. Experience with surgery for entrapment syndrome of the suprascapular nerve. Ortop Traumatol Rehabil 2007;9:128-33.

4. Bahadır C, Topatan S, Taraktaş A, Akgün K. Suprascapular nerve neuropathy: A case report. Turk J Phys Med Rehab 2008;54:11923.

5. Karataş GK, Göğüş F. Suprascapular nerve entrapment in newsreel cameramen. Am J Phys Med Rehabil 2003;82:192-6.

6. Boykin RE, Friedman DJ, Zimmer ZR, Oaklander AL, Higgins LD, Warner JJ. Suprascapular neuropathy in a shoulder referral practice. J Shoulder Elbow Surg 2011;20:983-8.

7. Araujo MG, Fragoso YD. Occupational lesion of the suprascapular nerve leading to marked atrophy of the supra- and infraspinatus muscles. J Clin Neuromuscul Dis 2004;6:22-3.

8. Velioğlu O, Yıldızgören MT, Turhanoğlu AD. Isolated suprascapular neuropathy: A cause of subluxation or a result of subluxation. Turk J Osteoporos 2015;21:100-100.

9. Khan AA, Ahmad K, Bin Ayaz S, Ayyub A. Suprascapular nerve injury at the spinoglenoid notch in a washer man: A Case Report. Cukurova Med J 2014;39:143-6.

10. Alkan B, Ömür D, Oğuzalp H, Akman T, Cosar M. Supraskapular sinir tuzaklanması olgu sunumu. Anatol J Clin Investig 2015;9:1468.

11. Güner Ç, Filiz MB, Doğan ŞK, Çakır T, Çeken Ç, Toslak iE, et al. Recurrent suprascapular nerve entrapment by spinoglenoid notch cyst: A case report. J Clin Anal Med 2014;5(Suppl 1):38-40.

12. Walsworth MK, Mills JT 3rd, Michener LA. Diagnosing suprascapular neuropathy in patients with shoulder dysfunction: a report of 5 cases. Phys Ther 2004;84:359-72.

13. Economides $C P$, Christodoulou L, Kyriakides T, Soteriades ES. An unusual case of suprascapular nerve neuropathy: a case report. J Med Case Rep 2011;5:419.

14. Cummins CA, Messer TM, Nuber GW. Suprascapular nerve entrapment. J Bone Joint Surg Am 2000;82:415-24.

15. Hill LJ, Jelsing EJ, Terry MJ, Strommen JA. Evaluation, treatment, and outcomes of suprascapular neuropathy: a 5-year review. PM R 2014;6:774-80.

16. Boykin RE, Friedman DJ, Higgins LD, Warner JJ. Suprascapular neuropathy. J Bone Joint Surg Am 2010;92:2348-64. 